\title{
Basal Adare volcanics, Robertson Bay, North Victoria Land, Antarctica: Late Miocene intraplate basalts of subaqueous origin
}

\author{
N. Mortimer, ${ }^{1}$ W.J. Dunlap, ${ }^{2}$ M.J. Isaac, ${ }^{3}$ R.P. Sutherland, ${ }^{3}$ and K. Faure $^{3}$ \\ ${ }^{1}$ GNS Science, Private Bag 1930, Dunedin, New Zealand (n.mortimer@gns.cri.nz) \\ ${ }^{2}$ Research School of Earth Sciences, Australian National University, Canberra, ACT, Australia. Present address: Dept. of Geology \& Geophysics, \\ University of Minnesota, Minneapolis, MN 55455, USA \\ ${ }^{3}$ GNS Science, PO Box 30368, Lower Hutt, New Zealand
}

\begin{abstract}
Late Cenozoic lavas and associated hyaloclastite breccias of the Adare volcanics (Hallett volcanic province) in Robertson Bay, North Victoria Land rest unconformably on Paleozoic greywackes. Abundant hyaloclastite breccias are confined to a paleovalley; their primary geological features, and the stable isotope ratios of secondary minerals, are consistent with eruption in a subaqueous environment with calcite formation probably involving seawater. In contrast, the lavas which stratigraphically overlie the hyaloclastites on Mayr Spur probably were erupted subaerially. $\mathrm{K}-\mathrm{Ar}$ dating of eight samples from this basal sequence confirms the known older age limit (Late Miocene) of the Hallett volcanic province. Geochemical data reveal an ocean island basalt-like affinity, similar to other Cenozoic igneous rocks of the Hallett volcanic province. If a submarine eruptive paleoenvironment is accepted then there has been net tectonic or isostatic post-Late Miocene uplift of a few hundred metres in the Robertson Bay-Adare Peninsula area.
\end{abstract}

Citation: Mortimer, N., W.J. Dunlap, M.J. Isaac, R.P. Sutherland, and K. Faure (2007), Basal Adare volcanics, Robertson Bay, North Victoria Land, Antarctica: Late Miocene intraplate basalts of subaqueous origin, in Antarctica: A Keystone in a Changing World - Online Proceedings of the $10^{\text {th }}$ ISAES, edited by A.K. Cooper and C.R. Raymond et al., USGS Open-File Report 2007-1047, Short Research Paper 045, 7 p.; doi:10.3133/of2007-1047.srp045

\section{Introduction}

The McMurdo Volcanic Group (MVG) extends for some $800 \mathrm{~km}$ along the western margin of the Ross Sea and consists mainly of alkaline lavas of Cenozoic age. The northern end of the MVG is called the Hallett volcanic province (HVP) (Hamilton, 1972; McIntosh and Kyle, 1990; Läufer et al. 2005) and extends for some 260 $\mathrm{km}$ from Cape Adare to Coulman Island (Figure 1). The HVP has been the subject of numerous reconnaissance, and some more detailed, studies (e.g. Harrington et al., 1967; Hamilton, 1972; Jordan, 1981; McIntosh and Gamble, 1989; McIntosh and Kyle, 1990; Müller et al.,1991; Rocchi et al., 2002, 2003; Nardini et al., 2003). A summary of HVP ages by Rocchi et al. (2003) showed that alkaline magmatism started at c. 48 Ma (Middle Eocene). The Adare volcanics, which form the northern part of the HVP, are relatively unstudied: two small areas in the Adare volcanics near the head of Robertson Bay were mapped in detail by the first GANOVEX expedition (Jordan 1981), and some Late Miocene K-Ar dates published from their middle and upper stratigraphic units on Mayr Spur and Adare Peninsula (Kreuzer et al. 1981; Müller et al. 1991).

The main objective of our field work in Robertson Bay during December 2005 was to sample Paleozoic greywacke basement for a U-Th-He dating study of exhumation at the northern termination of the Transantarctic Mountains. Earlier studies (Fitzgerald and Gleadow, 1988; Lisker, 2002) had indicated an episode of rapid cooling and exhumation at c. 50-55 Ma. A secondary objective of the field work was to establish the age and petrochemistry of basal Adare Volcanics and nearby dikes that were mapped, but not analysed, by Jordan (1981). This was done in order to establish if there

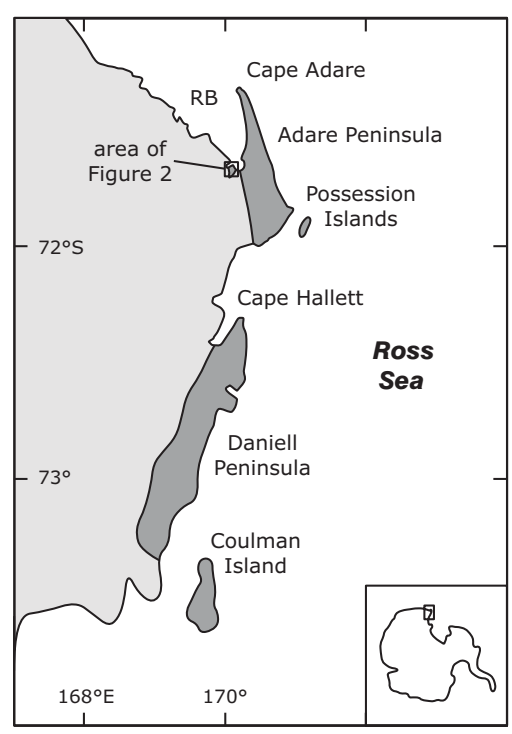

Figure 1. Location of the Hallett volcanic province (dark grey). RB=Robertson Bay.

were any pre-Late Miocene igneous rocks in the Cape Adare area whose geochemistry might record major Cenozoic tectonomagmatic change in the mantle and/or crust beneath North Victoria Land. Speculatively, this change might be related to the $55 \mathrm{Ma}$ on land exhumation or to spreading in the offshore Adare Trough inferred to have started at c. $43 \mathrm{Ma}$ and stopped at c. $26 \mathrm{Ma}$ (Cande et al., 2000). The purpose of this short paper is to present the results of our observations, analyses and interpretations of the basal Adare volcanics on Mayr Spur, south of Protection Cove. 


\section{Methods}

Samples for geochemical analysis were ground in a tungsten carbide ring mill. Analyses of quartz blanks crushed at GNS Science have revealed no issues with $\mathrm{Nb}$ or Ta contamination for normal sized samples (see also Roser et al., 2003). Powders were analysed by X-ray fluorescence analysis at Spectrachem Analytical Wellington (Kennedy et al., 1983), and by ICP-MS analysis of nebulized, dissolved, fused beads at Washington State University, Pullman (Knaack et al., 1994). K-Ar ages were determined at Australian National University following methods outlined in Dalrymple and Lanphere (1969). Care was taken to avoid dating samples with any amygdules, vesicles, iddingsitised olivine or secondary calcite.

Oxygen isotope analyses of silicate samples were analysed by $\mathrm{CO}_{2}$-laser fluorination using $\mathrm{BrF}_{5}$ as the reagent, similar to the method described by Sharp (1990). Values were normalised to the international quartz standard, NBS 28, assuming a value of $9.64 \%$, relative to VSMOW. Analytical precision for the NBS 28 standard ( $\mathrm{n}=3)$ was better than $0.1 \%$ ( 1 sigma). Calcite was analysed for $\delta^{18} \mathrm{O}$ and $\delta^{13} \mathrm{C}$ values by crushing samples to a fine-powder and reacting with phosphoric acid at $50{ }^{\circ} \mathrm{C}$ for 2 hours (McCrea, 1950). Oxygen isotope values were corrected using the appropriate phosphoric acid - $\mathrm{CO}_{2}$ fractionation factors (Rosenbaum and Sheppard, 1986). All carbonate measurements are normalised to VPDB $\left(\delta^{13} \mathrm{C}=1.95 \%\right)$ and VSMOW $\left(\delta^{18} \mathrm{O}\right.$ $=28.6 \%$ ) using NBS-19 and checked for accuracy by also analysing an internal standard (GNS Marble). Replicates of carbonate standards $(n=4)$ were better than $0.1 \%$ for carbon and oxygen values.

\section{Field observations}

General sketch geological maps of the whole Adare Peninsula were made by Hamilton (1972) and McIntosh and Kyle (1990). They suggested that it represented the highly breached and eroded western part of a shield volcano. One of Jordan's (1981) two mapped areas was a section of lavas and volcaniclastic rocks on the Adare Peninsula east of Protection Cove (east of Figure 2; see Jordan, 1981, figure 5). Jordan divided this $1500 \mathrm{~m}$ thick sequence into five units (A-E) of interlayered palagonite breccias, basaltic lavas, trachytes and tuffs; with neither the top nor bottom of the section exposed. The other area (Jordan, 1981, figure 3) was immediately south of Protection Cove (including Mayr Spur) where palagonitized hyaloclastite breccias occupied the base and sides of a paleovalley carved into greywacke basement and were overlain by olivine basalt lavas.

Our fieldwork south of Protection Cove (Figure 2) confirms the general position of the volcanic-basement contact as shown by Jordan. The topographically lowest part of the unconformity is almost at present day sea level at Protection Cove and rises to more than $400 \mathrm{~m}$ on Mayr Spur. Hyaloclastite breccias and tuffs are more

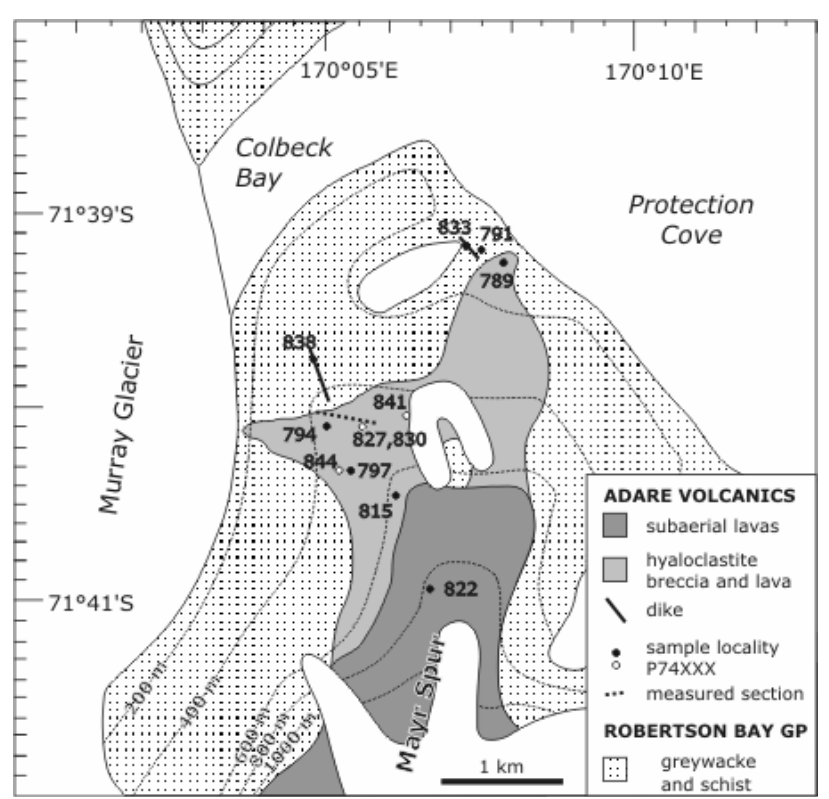

Figure 2. Simplified geological map of the Adare Volcanics south of Protection Cove. Modified after Jordan (1981). Measured section refers to the stratigraphic column reported in Figure 3. Contours approximate.

widespread in the topographically lower parts of the section. We have divided the Adare volcanics into two main units, a stratigraphically lower unit dominated by subaqueous hyaloclastite breccias and tuffs cut by irregular olivine basalt dikes, sills and plugs, and a stratigraphically higher unit on Mayr Spur dominated by slaggy and reddish coloured olivine basalt flows which we interpret as being subaerially erupted (Figure 2). Two linear north-north-west-striking dikes were also mapped. Both dikes intrude basement greywacke on the north-west side of the paleovalley but, because of obscured outcrop, cannot not be traced to the greywacke-Adare volcanics contact. The northern dike, exposed near Protection Cove consists of fresh basalt with large plagioclase phenocrysts, is 2-5 m wide, has an orientation of $140 /$ vertical and can be traced continuously for $85 \mathrm{~m}$; the southern dike is equigranular and more altered, $0.5-1 \mathrm{~m}$ wide, has an orientation of $165 / 80 \mathrm{~W}$ and can be traced discontinuously for $420 \mathrm{~m}$.

A section measured through part of the lower unit is shown in Figure 3. More than $90 \%$ of the lower unit consists of orange-brown massive and structureless, matrix-supported, unsorted to poorly sorted hyaloclastite breccia (Figure 4A, B, C). Clasts range in size from $<0.5$ to $>20 \mathrm{~cm}$ and typically consist of $50-80 \%$ quenched glassy basalt clasts (now largely altered to orange-brown palagonite), $15-30 \%$ varitextured but holocrystalline olivine basalt clasts and 5-15\% greywacke and argillite clasts. The vesicularity of the glassy clasts averages $20 \%$ but ranges from $0-50 \%$. In thin section most vitric clasts are not straight sided but, like the holocrystalline clasts, 
have outwardly convex shapes and show evidence of transport and abrasion rather than simple thermal fracturing (Figure 4C). Many of the larger basalt clasts show bulbous forms indicative of injection and disaggregation into water and/or wet sediment (e.g. Jordan, 1981, figure 4); they are disaggregated pillows. Calcite is a common secondary mineral and is present in amygdules, as breccia cement between clasts, and in cross-cutting veins.
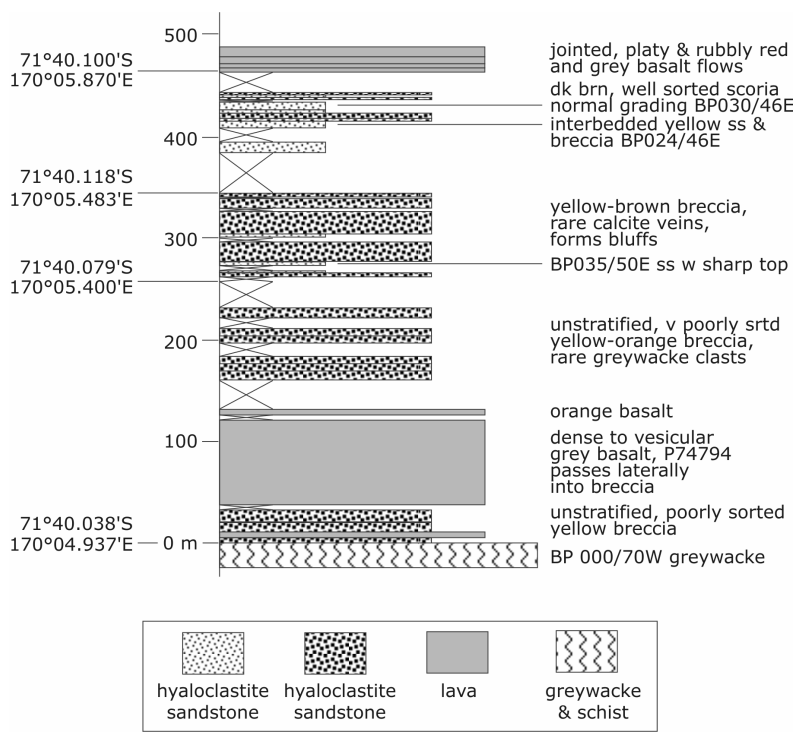

Figure 3. Measured section through the topographically lower hyaloclastite breccia sequence of Adare volcanics south of Protection Cove. Note section profile was measured along slope, and is not perpendicular to any particular reference plane. See Figure 2 for location.

About 5\% of the lower unit consists of sandstones and mudstones locally intercalated with the breccias (Figure 3). These rocks are better sorted (e.g. Figure 4D), are sometimes graded and show subhorizontal to moderately-dipping bedding. Cross-bedding indicating a north-to-south paleocurrent was observed at one location. These finer grained sediments are present near sea level at Protection Cove, but also occur scattered up to above 400 m elevation; there appears to be no overall upwards or lateral fining or coarsening trend.

The aforementioned sedimentary rocks are intruded, and sometimes clearly altered and reddened, by irregular olivine basalt dikes and sills that form up to $5 \%$ of the lower stratigraphic unit. In places substantial columnarjointed plugs, up to $20 \mathrm{~m}$ across and surrounded by breccia on all sides (greywacke in the case of one near the Protection Cove coast), indicate more substantial magma conduits. In some places the margins of the plugs, dikes and sills show convex, pillow-like, protrusions against the breccia.

\section{Age}

Previous dating of the Adare Peninsula lavas consists of one whole rock K-Ar age of $2.3 \pm 0.5 \mathrm{Ma}$ from the southernmost Adare Peninsula (Hamilton, 1972; Armstrong, 1978), and 24 whole rock K-Ar ages from the Adare Peninsula and Mayr Spur (Kreuzer et al., 1981; Müller et al., 1991). With the exception of a $1.1 \pm 0.1 \mathrm{Ma}$ age from Jordan's (1981) topmost unit E, seven ages from units $\mathrm{D}$ and $\mathrm{E}$ ranged from 6.8 to $8.3 \mathrm{Ma}$, four ages from unit $\mathrm{C}$ ranged from 9.9 to $13.2 \mathrm{Ma}$ and six ages from unit $\mathrm{B}$ ranged from 10.9 to $13.8 \mathrm{Ma}$. Two lavas from Cape Adare were dated at $3.8 \mathrm{Ma}$. No ages were reported from the lower volcaniclastic unit A, nor from dikes that cut nearby Robertson Bay Group basement.

Our sample set consisted of a variety of igneous material from different parts of the basal Adare volcanics on Mayr Spur. This comprised two basaltic dikes intruding basement greywacke, one lava from the subaerial sequence at $1085 \mathrm{~m}$ elevation, and five basalt plugs intruded into hyaloclastite breccia (Table 1). The eight ages range from $9.7 \pm 0.2 \mathrm{Ma}$ to $10.6 \pm 0.2 \mathrm{Ma}$. Neither the dikes nor the stratigraphically higher sample (which would be from Jordan's unit B) give ages significantly younger than the basalts from the valleyinfill hyaloclastite breccias. We infer that the entire volcanic-volcaniclastic-hypabyssal suite south of Protection Cove and on Mayr Spur could well have been emplaced in one eruptive cycle, possibly with eruptions being fed laterally by the dikes.
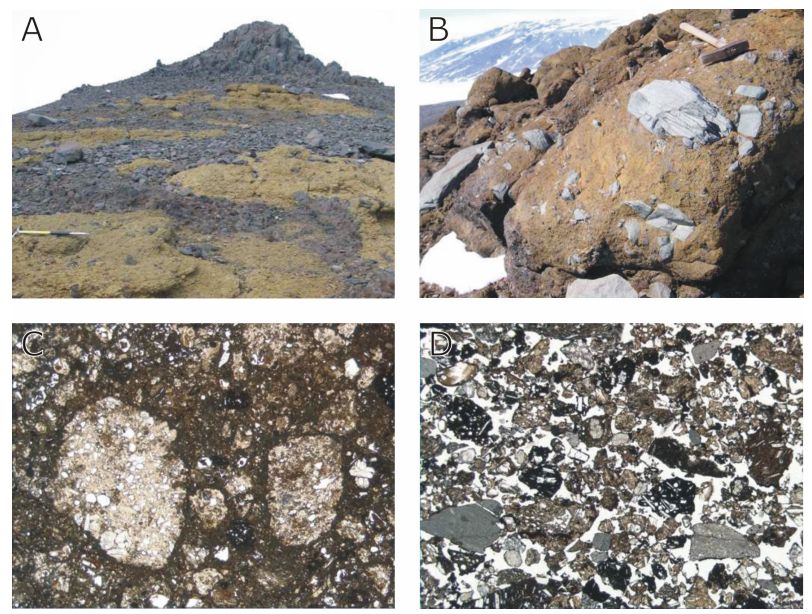

Figure 4. A. Basalt plug and dikes (reddish grey, darker) that intrude the hyaloclastite breccia unit (orange-brown, lighter). The dark material between the two boulders in the middle ground is talus. B. Hyaloclastite breccia containing exceptionally large and outsized greywacke basement clasts. Crude bedding dips $40^{\circ}$ to the east (right in the picture). C. Thin section image of matrix-rich portion of typical hyaloclastite breccia (P74826) plane polarized light, width $8 \mathrm{~mm}$. D. Thin section image of rare, unoxidised well-sorted, highly porous, coarse sandstone (P74839), width 8mm, plane polarized light. 
Table 1. Whole rock analytical data for Adare basalts

\begin{tabular}{|c|c|c|c|c|c|c|c|c|}
\hline Sample & P74789 & P74791 & P74794 & P74797 & P74815 & P74822 & P74833 & P74838 \\
\hline Latitude (deg) & -71.6544 & -71.6531 & -71.6681 & -71.6722 & -71.6744 & -71.6824 & -71.6529 & -71.6626 \\
\hline Longitude (deg) & 170.1310 & 170.1246 & 170.0839 & 170.0897 & 170.1021 & 170.1111 & 170.1226 & 170.0780 \\
\hline GPS elevation (m) & 45 & 75 & 344 & 460 & 683 & 1085 & 67 & 271 \\
\hline Rock & Plug & Plug & Plug & Plug & Upper flow & Upper flow & $\mathrm{N}$ dike & $\mathrm{S}$ dike \\
\hline \multicolumn{9}{|l|}{$X$-ray fluorescence } \\
\hline $\mathrm{SiO}_{2}(\mathrm{wt} \%)$ & 45.40 & 47.89 & 46.62 & 45.65 & 46.34 & 47.78 & 48.35 & 44.86 \\
\hline $\mathrm{TiO}_{2}$ & 3.40 & 2.71 & 2.43 & 3.70 & 3.68 & 2.83 & 2.07 & 3.95 \\
\hline $\mathrm{Al}_{2} \mathrm{O}_{3}$ & 16.32 & 17.08 & 13.56 & 16.64 & 16.92 & 16.01 & 15.95 & 17.51 \\
\hline $\mathrm{Fe}_{2} \mathrm{O}_{3} \mathrm{~T}$ & 14.07 & 13.48 & 12.29 & 14.4 & 14.13 & 12.96 & 11.16 & 15.16 \\
\hline $\mathrm{MnO}$ & 0.18 & 0.19 & 0.17 & 0.18 & 0.18 & 0.18 & 0.16 & 0.19 \\
\hline $\mathrm{MgO}$ & 6.06 & 3.97 & 9.20 & 5.53 & 5.04 & 6.05 & 7.94 & 2.40 \\
\hline $\mathrm{CaO}$ & 9.04 & 7.02 & 11.00 & 8.07 & 7.42 & 8.99 & 10.1 & 8.15 \\
\hline $\mathrm{Na}_{2} \mathrm{O}$ & 3.03 & 3.93 & 2.39 & 3.46 & 3.54 & 3.25 & 2.80 & 3.39 \\
\hline $\mathrm{K}_{2} \mathrm{O}$ & 1.23 & 1.90 & 0.92 & 1.24 & 1.31 & 1.27 & 0.99 & 1.32 \\
\hline $\mathrm{P}_{2} \mathrm{O}_{5}$ & 0.50 & 0.76 & 0.37 & 0.52 & 0.58 & 0.48 & 0.37 & 0.57 \\
\hline LOI & 0.19 & 0.57 & 0.54 & 0.14 & 0.30 & -0.17 & -0.48 & 1.97 \\
\hline Total & 99.42 & 99.50 & 99.49 & 99.53 & 99.44 & 99.63 & 99.41 & 99.47 \\
\hline $\mathrm{Sc}(\mathrm{ppm})$ & 26 & 17 & 31 & 24 & 20 & 25 & 21 & 26 \\
\hline $\mathrm{V}$ & 246 & 135 & 259 & 235 & 211 & 227 & 180 & 276 \\
\hline $\mathrm{Cr}$ & 39 & 4 & 477 & $<1$ & $<1$ & 143 & 304 & $<1$ \\
\hline $\mathrm{Ni}$ & 35 & 14 & 150 & 22 & 14 & 50 & 99 & 25 \\
\hline $\mathrm{Cu}$ & 32 & 27 & 69 & 20 & 16 & 31 & 28 & 23 \\
\hline $\mathrm{Zn}$ & 101 & 96 & 88 & 89 & 88 & 91 & 74 & 105 \\
\hline $\mathrm{Ga}$ & 24 & 20 & 19 & 21 & 21 & 21 & 18 & 22 \\
\hline As & 2 & 2 & 1 & 5 & $<1$ & 1 & $<1$ & 7 \\
\hline \multicolumn{9}{|l|}{ ICPMS fused bead } \\
\hline $\mathrm{Rb}$ (ppm) & 22.0 & 35.2 & 20.5 & 23.5 & 21.9 & 28.3 & 22.9 & 18.5 \\
\hline $\mathrm{Sr}$ & 720 & 857 & 477 & 776 & 902 & 626 & 585 & 926 \\
\hline Y & 27.8 & 30.2 & 23.9 & 29.0 & 29.6 & 28.2 & 21.8 & 29.6 \\
\hline $\mathrm{Zr}$ & 211 & 271 & 167 & 228 & 219 & 216 & 160 & 235 \\
\hline $\mathrm{Nb}$ & 56.4 & 82.1 & 41.3 & 61.6 & 62.6 & 55.1 & 40.1 & 63.2 \\
\hline Cs & 0.16 & 0.17 & 0.15 & 0.19 & 0.10 & 0.35 & 0.12 & 2.17 \\
\hline $\mathrm{Ba}$ & 306 & 447 & 236 & 326 & 348 & 317 & 252 & 373 \\
\hline $\mathrm{La}$ & 38.7 & 57.3 & 29.8 & 40.5 & 43.8 & 38.4 & 29.0 & 43.0 \\
\hline $\mathrm{Ce}$ & 78.2 & 112 & 61.1 & 82.4 & 88.7 & 78.0 & 58.3 & 87.2 \\
\hline $\operatorname{Pr}$ & 9.56 & 13.0 & 7.54 & 10.1 & 10.7 & 9.48 & 7.01 & 10.6 \\
\hline $\mathrm{Nd}$ & 38.3 & 49.1 & 30.3 & 40.3 & 42.1 & 37.8 & 27.8 & 42.6 \\
\hline $\mathrm{Sm}$ & 8.09 & 9.42 & 6.60 & 8.54 & 8.67 & 7.86 & 5.81 & 8.96 \\
\hline $\mathrm{Eu}$ & 2.74 & 3.01 & 2.23 & 2.92 & 3.01 & 2.58 & 1.95 & 3.09 \\
\hline Gd & 7.24 & 8.14 & 6.16 & 7.90 & 7.85 & 7.20 & 5.36 & 8.21 \\
\hline $\mathrm{Tb}$ & 1.12 & 1.17 & 0.94 & 1.16 & 1.17 & 1.09 & 0.82 & 1.22 \\
\hline Dy & 6.22 & 6.50 & 5.22 & 6.38 & 6.43 & 6.07 & 4.67 & 6.73 \\
\hline Ho & 1.13 & 1.19 & 0.98 & 1.18 & 1.21 & 1.15 & 0.87 & 1.24 \\
\hline $\mathrm{Er}$ & 2.82 & 3.03 & 2.43 & 2.93 & 2.95 & 2.9 & 2.22 & 3.05 \\
\hline $\mathrm{Tm}$ & 0.36 & 0.41 & 0.32 & 0.38 & 0.39 & 0.39 & 0.29 & 0.40 \\
\hline $\mathrm{Yb}$ & 2.12 & 2.40 & 1.85 & 2.20 & 2.22 & 2.23 & 1.74 & 2.30 \\
\hline $\mathrm{Lu}$ & 0.33 & 0.37 & 0.27 & 0.34 & 0.35 & 0.35 & 0.27 & 0.35 \\
\hline $\mathrm{Hf}$ & 5.47 & 6.65 & 4.32 & 5.68 & 5.44 & 5.35 & 3.99 & 5.88 \\
\hline Тa & 3.72 & 5.43 & 2.67 & 3.98 & 4.25 & 3.56 & 2.56 & 4.23 \\
\hline $\mathrm{Pb}$ & 2.05 & 2.86 & 1.87 & 1.91 & 2.18 & 2.71 & 2.13 & 2.12 \\
\hline Th & 4.38 & 6.93 & 3.78 & 4.61 & 4.92 & 4.96 & 4.02 & 4.78 \\
\hline $\mathrm{U}$ & 1.04 & 1.00 & 0.96 & 1.26 & 2.17 & 1.17 & 0.92 & 3.94 \\
\hline \multicolumn{9}{|c|}{ K-Ar dating of groundmass } \\
\hline $\mathrm{K}(\mathrm{wt} \%)$ & 0.988 & 1.43 & 0.868 & 1.01 & 1.13 & 1.06 & 0.934 & 1.11 \\
\hline${ }^{40} \mathrm{Ar}^{*}\left(10^{-11} \mathrm{~mol} / \mathrm{g}\right)$ & 1.78 & 2.41 & 1.54 & 1.85 & 1.97 & 1.86 & 1.72 & 1.94 \\
\hline${ }^{40} \mathrm{Ar} *(\%)$ & 40 & 66 & 39 & 67 & 67 & 44 & 59 & 46 \\
\hline Age (Ma) & 10.4 & 9.7 & 10.2 & 10.5 & 10.0 & 10.1 & 10.6 & 10.0 \\
\hline Error $(2 \sigma)$ & 0.4 & 0.4 & 0.4 & 0.4 & 0.4 & 0.4 & 0.4 & 0.4 \\
\hline
\end{tabular}

LOI=loss on ignition. Negative LOIs for some samples arise from the lavas being ferrous and anhydrous. K-Ar dated material is basalt groundmass, magnetically cleaned and density filtered to remove heavy minerals. Identical splits were used for both $\mathrm{K}$ and Ar concentration measurements. Decay constants are $\lambda_{\mathrm{e}}=0.581 \times 10^{-10} \mathrm{y}^{-1}$ and $\lambda_{\beta}=4.962 \times 10^{-10} \mathrm{y}^{-1}$ (Steiger and Jäger, 1977). For more sample details visit http://pet.gns.cri.nz 
The new age data do not extend the age of the Adare volcanics back in time any further than that published by Müller et al. (1991). In fact our 9.7-10.6 Ma age range of carefully selected and processed basalts is slightly younger and more tightly grouped than the 10.9-13.8 Ma GANOVEX ages from unit B. Late Miocene ages (as old as $12 \mathrm{Ma}$ ) have also been obtained from HVP in the Daniell Peninsula area (Figure 1; Nardini et al. 2003).

\section{Geochemistry}

\section{Igneous rocks}

Some chemical analyses of lavas from the main Adare Peninsula were published by Hamilton (1972) and McIntosh and Kyle (1990), and there is a more substantial analytical dataset of Hallett volcanics from further south (e.g. Müller et al., 1991; Nardini et al., 2003). In Table 1, we present the first geochemical data on the basal Adare volcanics south of Protection Cove, and also the first complete trace element analyses of any Adare volcanics.
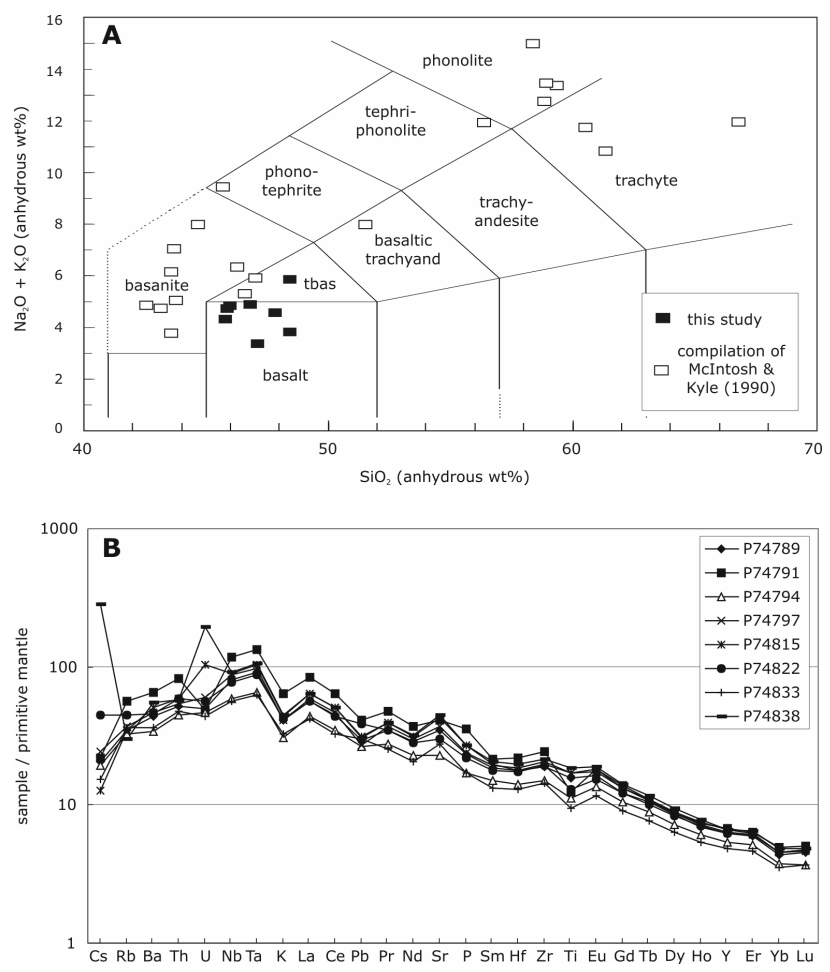

Figure 5. Lava and dike compositions from the study area plotted on A. Silica versus total alkalies diagram (after Le Maitre et al., 1989); B. multi-element normalised diagram after Sun and McDonough (1989).

All eight analysed lavas are basalts and show limited compositional range and good chemical coherence (Figure 5). Trachytes and phonolites have been reported from the Adare Peninsula (Hamilton, 1972; McIntosh and Kyle, 1990) but, despite a wide range in $\mathrm{Cr}$ and $\mathrm{MgO}$, none of our samples obviously fall outside the basalt compositional range (Table 1). The most altered sample, as shown by unusually high $\mathrm{Cs}$ and $\mathrm{U}$ content in the multi-element normalised diagram, is the southern dike, P74838. This is also the only analysed rock to show any significant weathering, although the plagioclase is fresh and the rock gives a similar K-Ar age to the other basalts (Table 1).

The multi-element primitive-mantle normalised diagrams have the convex-upward patterns, with small negative $\mathrm{K}$ and $\mathrm{Pb}$ anomalies, that are characteristic of ocean island basalt (OIB) suites (Sun and McDonough, 1989). The least $\mathrm{Cr}$ and $\mathrm{MgO}$-rich samples have the highest concentrations of incompatible elements. Similar OIB-like compositions have been reported for HVP at the Daniell Peninsula, south of Cape Hallett (Nardini et al. 2003).

Table 2 Stable isotope analytical data.

\begin{tabular}{lrrrrrr}
\hline Sample & 74794 & 74841 & 74830 & 74827 & $74844 \mathrm{~B}$ & $74844 \mathrm{~W}$ \\
Lat & -71.6681 & -71.6682 & -71.6688 & -71.6688 & -71.6721 & -71.6721 \\
Long 170.0839 & 170.0986 & 170.0902 & 170.0902 & 170.0861 & 170.0861 \\
$\begin{array}{l}\text { Elev (m) } \\
\text { Material }\end{array}$ & Rock & Rock & Calcite & Calcite & Calcite & Calcite \\
Notes & Fresh & altered & amyg vein 1mm & vein 2cm & vein 2cm \\
& lava & breccia & in lava & white & brown & white \\
& & & & & & \\
$\delta^{18} \mathrm{O}$ & 5.5 & 5.8 & 12.6 & 11.4 & 10.7 & 11.7 \\
duplicate & 5.4 & 6.0 & - & - & - & 11.9 \\
$\delta^{13} \mathrm{C}$ & - & - & 0.0 & 0.8 & 2.2 & -0.5 \\
duplicate & - & - & - & - & - & -0.4 \\
\hline
\end{tabular}

Latitude and longitude in decimal degrees, $\delta^{18} \mathrm{O} \%$ VSMOW, $\delta^{13} \mathrm{C} \%$ VPDB.

\section{Stable isotope analyses}

Oxygen and carbon isotope analyses were made on three samples of calcite veins cutting hyaloclastite breccia, one sample of calcite amygdules in lava, one sample of hyaloclastite breccia matrix (that X-ray diffraction showed comprised c. $15 \%$ smectite) and one fresh basalt. This was done to help assess whether the breccias formed from interaction of basalt with seawater or with Antarctic meteoric water. The fresh basalt gives a mantle-like $\delta^{18} \mathrm{O}$ value of $+5.5 \%$. The stable isotope values of the calcite veins and amygdules are consistent with having formed from a fluid with seawater $\delta^{18} \mathrm{O}$ and $\delta^{13} \mathrm{C}$ values at c. $150^{\circ} \mathrm{C}$ (using fractionation factors of O'Neil et al., 1969 and Sheppard and Gilg, 1996), the temperature being consistent with the smectite alteration. Based on the $\delta^{18} \mathrm{O}$ values of the calcites, the lowest reasonable calculated $\delta^{18} \mathrm{O}$ value of the water would be $22 \%$ with a temperature of $1{ }^{\circ} \mathrm{C}$; this is not low enough to be pure Antarctic melt water (typically between -30 and 25\%, Nancy Bertler, pers. comm., 2007). Calculations show that the smectite-rich breccia was altered either by $150-200^{\circ} \mathrm{C}$ seawater, or by $<<50^{\circ} \mathrm{C}$ Antarctic melt water. In view of the abundant evidence for hydroclastic fragmentation of pillow fragments in the breccias, we tentatively interpret the secondary alteration to have taken 
place at moderate $\left(150-200^{\circ} \mathrm{C}\right)$ temperatures, therefore also supporting an interaction primarily with seawater, not primarily with melted Antarctic ice.

\section{Paleoenvironment of eruption}

Unfortunately, the limited quality and quantity of our field observations do not allow us to rigorously explore a subglacial versus submarine origin for the hyaloclastite breccias. The extent of the breccias, up to $400 \mathrm{~m}$ vertical thickness filling in a paleovalley south of Protection Cove, and forming a c. $150 \mathrm{~m}$ thick stratigraphic unit east of Protection Cove, suggests that there has been very substantial magma-water interaction, probably more than would be expected from a subfluvial or a sublacustrine eruption. In both areas the hyaloclastite breccias are succeeded stratigraphically upward by a $>1000 \mathrm{~m}$ section dominated by lava flows whose reddish coloration is indicative of subaerial eruption (Jordan, 1981).

It seems fairly likely that the fundamental contact between lower hyaloclastite breccias and upper lava flows represents a change from subaqueous to subaerial eruption. It is not certain that this stratigraphic change represents a subglacial-subaerial passage zone as outlined by Smellie (2006), as the typical dipping delta front bedforms described by Smellie (2006) for subglacial volcanism are lacking. Most of the Adare volcanics hyaloclastite breccias we observed are structureless, and rare bedding in locally intercalated sandstones and mudstones has variable dips and does not define coherent large foresets. Subangular-subrounded greywacke basement clasts are distributed throughout the breccia and suggest a small but sustained input of till-derived material to the volcaniclastic-dominated depositional system.

As discussed earlier, the analysed calcite samples probably acquired their oxygen isotope signature from seawater. Technically the calcite occurrences (as amygdules and veins cutting breccia) represent postdepositional/eruptive crystallisation, however they could have formed in a syn- to immediately post-eruptional hydrothermal system that circulated within the breccia pile. Irrespective of the mode and time of formation, the presence of seawater-related calcite veins now at almost $400 \mathrm{~m}$ elevation suggests substantial post-eruptive uplift, as present day and Late Miocene eustatic sea levels were similar (Miller et al., 2005). This, too, has some caveats. Johnson and Smellie (2007) have cautioned that marine geochemical alteration may penetrate laterally into a mainly nonmarine volcanic pile. Furthermore, if a hydrothermal system was operating some penetration could also occur vertically. Thus the $400 \mathrm{~m}$ should be regarded as a speculative and maximum uplift.

McIntosh and Gamble (1989) presented evidence that substantial portions of the Adare volcanics on the Adare Peninsula erupted subaerially rather than subglacially or subaqueously. Evidence included Hawaiian or Strombolian pyroclastic deposits and accretionary lapilli interbedded with oxidised lavas. The volcanic sections exposed in the steep and high cliffs of the linear Adare
Peninsula attest to substantial post-Late Miocene marine erosion. An erosional bench, some $40 \mathrm{~m}$ above present day sea level, is cut into the greywacke and hyaloclastite breccia above the Protection Cove shoreline and, through binoculars, can be seen to continue up the west side of Adare Peninsula. This is probably a much younger, coastal erosion feature than the Miocene landscape features outlined by Armienti and Baroni (1999).

\section{Conclusions}

Our investigation confirms the earlier interpretations of Rocchi et al. (2002, 2003), that the Adare volcanics do not contain a record of geochemical change related to Paleogene tectonic events in North Victoria Land. The age of the basal Adare volcanics is reliably established as 10-11 Ma (Late Miocene). The lavas are alkali olivine basalts similar to OIB suites and lavas in the southern parts of the HVP. Our reconnaissance work on the paleoenvironment of eruption is less conclusive. Lithofacies evidence for a subglacial versus submarine paleoenvironment of eruption is equivocal but oxygen isotope analyses of secondary minerals suggest that the $>400 \mathrm{~m}$ paleovalley fill of hyaloclastite breccia, intruded by dikes and plugs, was possibly at or near sea level in the Late Miocene. This was succeeded, also in the 10-11 Ma interval, by subaerial lava flows also of OIB petrological affinity that are preserved at higher elevations, including along the Adare Peninsula. If our interpretation of a submarine, rather than subglacial, influence on secondary calcite material is correct then there appears to have been net tectonic or isostatic post-Late Miocene uplift of a few hundred metres in the Robertson Bay-Adare Peninsula area.

Acknowledgments We thank Davie Robinson, our able field assistant for the K104-0506 event. We are grateful to Antarctica New Zealand, and especially the efforts of Erik Barnes, for logistical support to get us to the event area. Local helicopter travel was provided by the Italian Antarctic programme. John Simes is thanked for technical assistance, and John Hunt, Charles Knaack, Ray Soong and Valerie Claypool for chemical and isotopic analyses. We have had useful communication with David Skinner, Solveig Estrada, Norbert Roland and Federico Rossetti. The manuscript was improved by comments from referees Sergio Rocchi, John Smellie and co-editor Phil Kyle. Funded by the New Zealand Foundation for Research, Science and Technology.

\section{References}

Armienti, P., and C. Baroni (1999), Cenozoic climatic change in Antarctica recorded by volcanic activity and landscape evolution, Geology, 27, 617-620.

Armstrong, R.L. (1978), K-Ar dating: Late Cenozoic McMurdo Volcanic Group and Dry Valley glacial history, Victoria Land, Antarctica, N.Z. J. Geol. Geophys., 21, 685-698.

Cande, S.C., J.M. Stock, R.D. Müller, and T. Ishihara (2000), Cenozoic motion between East and West Antarctica, Nature, 404, 145-150.

Dalrymple, B.G., and M.A. Lanphere (1969), Potassium-Argon Dating: Principles, Techniques, and Applications to Geochronology, W.H Freeman and Company, San Francisco, 258pp.

Fitzgerald, P.G., and A.J.W. Gleadow (1988), Fission-track geochronology, tectonics and structure of the Transantarctic Mountains in northern Victoria Land, Antarctica, Chem. Geol., 73, 169-198.

Hamilton, W. (1972), The Hallett Volcanic Province, Antarctica, U.S.G.S. Prof. Paper, 456C, 62pp. 
Harrington, H.J., B.L. Wood, I.C. McKellar, and G.J. Lensen (1967), Topography and geology of the Cape Hallett District, Victoria Land, Antarctica, N.Z.G.S. Bull., 80, 100pp.

Johnson, J.A., and J.L. Smellie (2007), Zeolite compositions as proxies for eruptive paleoenvironment, Geochemistry, Geophysics, Geosystems, 8, Q03009, doi:10.1029/2006GC001450.

Jordan, H. (1981), Tectonic observations in the Hallett Volcanic Province, Antarctica, Geol. Jahrb., B41, 111-125.

Kennedy, P.C., B.P. Roser, and J.L. Hunt (1983), Analyses of the USGS geochemical reference samples GXR-1 to 6, Geostandards Newsletter 7.

Knaack, C., S. Cornelius, and P.R. Hooper (1994), Trace element analyses of rocks and minerals by ICP-MS, Open File Report. Department of Geology, Washington State University, Pullman, USA.

Kreuzer, H., A. Höhndorf, H. Lenz, U. Vetter, F. Tessensohn, P. Müller, H. Jordan, W. Harre, and C. Besang (1981), K/Ar and Rb/Sr dating of igneous rocks from North Victoria land, Antarctica, Geol. Jahrb., B41, 267-273.

Läufer, A.L., G. Kleinschmidt, F. Henjes-Kunst, F. Rossetti, and C. Faccenna (2005), Geological map of the Cape Adare quadrangle, Victoria Land, Antarctica, 1:250 000. GIGAMAP - German-Italian Geological Antarctic Map Programme. Bundesanstalt für Geowissenschaften und Rohstoffe, Hannover.

Le Maitre, R.W., and 11 others (1989), A Classification of Igneous Rocks and Glossary of Terms: Recommendations of the International Union of Geological Sciences Subcommission on the Systematics of Igneous Rocks, Blackwell, Oxford. 193 pp.

Lisker, F. (2002), Review of fission track studies in northern Victoria land, Antarctica-passive margin evolution versus uplift of the Transantarctic Mountains, Tectonophysics, 349, 57-73.

McIntosh, W.C., and J.A. Gamble, (1989), A subaerial eruptive environment for the Hallett Coast volcanoes, in Geological Evolution of Antarctica, edited by M.R.A. Thomson, J.A. Crame, and J.W. Thomson, pp. 657-661, Cambridge University Press.

McIntosh, W.C., and P.R. Kyle (1990), Hallett Volcanic Province, in Volcanoes of the Antarctic Plate and Southern Oceans, edited by W.E. LeMasurier, and J.W. Thomson, Antarctic Research Series, 48, pp.26-47, American Geophysical Union, Washington, D.C.

McCrea, J.M. (1950), On the isotopic chemistry of carbonates and palaeo-temperature scale, J. Chem. and Phys., 18, 849-857.

Miller, K.G., M.A. Kominz, J.V. Browning, J.D. Wright, G.S. Mountain, M.E. Katz, P.J. Sugarman, B.S. Cramer, N. Christie-Blick, and S.F. Pekar (2005), The Phanerozoic record of global sea-level change. Science, 310, 1293-1298.

Müller, P., M. Schmidt-Thome, H. Kreuzer, F. Tessensohn, and U. Vetter (1991), Cenozoic peralkaline magmatism at the western margin of the Ross Sea, Antarctica, Mem. Soc. Geol. Ital., 46, 315336.

Nardini, I., P. Armienti, S. Rocchi, and R. Burgess (2003), ${ }^{40} \mathrm{Ar}-{ }^{39} \mathrm{Ar}$ chronology and petrology of the Miocene rift-related volcanism of Daniell Peninsula (Northern Victoria Land, Antarctica), Terra Antartica, 10, 39-62.

O'Neil, J.R., R.N. Clayton, and T.K. Mayeda (1969), Oxygen isotope fractionation in divalent metal carbonates, J. Chemical Physics, 51, 5547-5558.

Rocchi, S., P. Armienti, M. D’Orazio, S. Tonarini, J.R. Wijbrans, and G. Di Vincenzo (2002), Cenozoic magmatism in the western Ross Embayment: role of mantle plume versus plate dynamics in the development of the West Antarctic Rift system, J. Geophys. Res., B107, 1-22.

Rocchi, S., F. Storti, G. Di Vincenzo, and F. Rossetti (2003), Intraplate strike-slip tectonics as an alternative to mantle plume activity for the Cenozoic rift magmatism in the Ross sea region, Antarctica, in Intraplate Strike-Slip Deformation Belts, edited by F. Storti, R.E. Holdsworth, and F. Salvini, Geol. Soc., London, Spec. Pub. 210, pp. 145-158, Blackwell, London.

Rosenbaum, J., and S.M.F. Sheppard (1986), An isotopic study of siderites, dolomites and ankerites at high temperatures, Geochim. Cosmochim. Acta, 50, 1147-1150.

Roser, B.P., J.I. Kimura, and K. Sifeta (2003), Tantalum and niobium contamination from tungsten carbide ring mills: much ado about nothing, Geosci. Rep. Shimane Univ. 22, 107-110.
Sharp, Z.D. (1990), Laser-based microanalytical method for the in situ determination of oxygen isotope ratios of silicates and oxides, Geochim. Cosmochim. Acta, 54, 1353-1357.

Sheppard, S.M.F., and H.A.Gilg (1996), Stable isotope geochemistry of clay minerals, Clay Minerals, 31, 1-24.

Smellie, J.L. (2006), The relative importance of supraglacial versus subglacial meltwater escape in basaltic subglacial tuya eruptions: An important unresolved conundrum, Earth Science Reviews, 74, 241268.

Steiger, R.H. and E. Jäger (1977), Subcommission on Geochronology: convention on the use of decay constants in geo- and cosmochronology, Earth Plan. Sci. Letters, 36, 359-362.

Sun, S.-S. and W.F. McDonough (1989), Chemical and isotopic systematics of oceanic basalts: implications for mantle composition and processes, in Magmatism in the Ocean Basins, edited by A.D. Saunders, and M.J. Norry, Geol. Soc., London, Spec. Pub. 42, pp. 313-345, Blackwell, London. 